\title{
KEBERADAAN PIDANA ADAT DALAM MAZHAB SEJARAH DIHUBUNGKAN DENGAN POSITIVISME HUKUM
}

\author{
ABSTRAK \\ Ateng Sudibyo \\ E-mail : atengsudibyo099@gmail.com
}

Hukum pidana adat berikut sanksi-sanksi adat diupayakan untuk dihapus dari sistem hukum di Indonesia dan diganti oleh peraturan perundang-undangan sehingga prosedur penyelesaian perkara-perkara pidana pada umumnya disalurkan melalui peradilan umum. Akan tetapi, kenyataannya sampai sekarang masih terdapat hakim-hakim yang mendasarkan putusannya pada hukum adat atau setidak-tidaknya pada hukum yang dianggap sebagai hukum adat dengan penafsirannya atas dasar Pasal 5 ayat 3 UU No. 1/Drt/1951 tentang TindakanTindakan Sementara Untuk Menyelenggarakan Kesatuan Susunan Kekuasaan Dan Acara Pengadilan-Pengadilan Sipil

Metode penelitian yang digunakan adalah penelitian hukum normatif yang bersifat deskriptif analisis, pengumpulan data dilakukan dengan menggunakan data primer dan data sekunder berupa bahan hukum primer, sekunder dan tertier sebagai data utama. Setelah data sekunder dan primer terkumpul, kemudian diadakan analisis secara kualitatif

Berdasarkan hasil analisis data, disimpulkan bahwa Aksiologi hukum pidana adat merupakan bahan hukum asli Indonesia yang sudah sepatutnya dijadikan sumber hukum positif. Namun, hingga saat ini hukum Indonesia masih menerapkan hukum Hindia Belanda. Eksistensi hukum pidana adat Indonesia berada pada tataran dogmatik hukum, teori hukum dan filsafat hukum. Oleh karena itu hukum pidana adat secara holistik menjiwai seluruh lapisan ilmu hukum yang pada hakikatnya hukum pidana adat tidak diragukan kapabilitasnya sebagai karakteristik praktek hukum di Indonesia. Dengan demikian eksistensi hukum pidana adat di masa yang akan datang, harus tetap mempunyai peranan yang penting, terutama dalam pembentukan hukum nasional yang akan datang.

\section{Kata Kunci: Pidana Adat, Mazhab Sejarah, Positivisme}

\footnotetext{
${ }^{1}$ Guru SMPN Satap Cengal Maja Majalengka.
} 


\section{A. Latar Belakang}

Perkembangan manusia dan interaksinya dalam memenuhi salah satu kebutuhan hidupnya terkadang menciptakan berbagai macam kejahatan dan pelanggaran, akan tetapi kejahatan dan pelanggaran tidak semuanya diatur dalam ketentuan hukum positif. Ketentuan hukum seringkali sudah banyak tertinggal dengan kemajuan-kemajuan masyarakat. Hal ini bukan berarti terjadi kekosongan hukum, namun hukum yang ada harus diisi dan ditemukan lebih lanjut melalui penemuan hukum. Sejalan dengan itu, dalam masa pembangunan ini, sebenarnya hukum tidak hanya diharapkan akan mampu berfungsi sebagai sarana pembaharuan masyarakat dan pengayom masyarakat, tetapi harus tampil di depan memberi arah pada pembentukan suatu masyarakat yang dicita-citakan. Oleh karena itu, yang perlu dilakukan adalah menata sistem hukum yang menyeluruh dan terpadu dengan mengakui dan menghormati hukum agama dan hukum adat termasuk hukum pidana adat.

Keberadaan Hukum Pidana Adat pada masyarakat merupakan pencerminan kehidupan masyarakat tersebut dan pada masing-masing daerah yang memiliki Hukum Pidana Adat yang berbeda sesuai dengan adat istiadat yang ada di daerah tersebut, dengan ciri khas tidak tertulis ataupun terkodifikasikan. Sedangkan sumber hukum pidana Indonesia adalah hukum pidana tertulis dan hukum pidana tidak tertulis. Sumber hukum pidana tertulis adalah KUHP yang berasal dari Wetboek van Strafrecht voor Nederlandsch Indie, yang mulai berlaku 1 Januari 1918. Sebelum 1 Januari 1918 di Hindia Belanda berlaku $2 \mathrm{WvS}$, ialah WvS untuk golongan Eropa berdasarkan K.B 1866 No.55 dan WvS untuk orang Bumiputra dan yang dipersamakan berdasarkan Ordinantie 6 Mei 1872. Dengan demikian, secara formal hukum pidana adat saat itu tidak diberlakukan oleh pemerintah penjajah Belanda di Hindia Belanda, walaupun secara materiil tetap berlaku dan tetap diterapkan dalam praktek peradilan. Namun dalam era kemerdekaan pemberlakuan hukum pidana adat, mendapat landasan hukum dengan dikeluarkannya UU No. 1 Drt 1951 tentang Tindakan-Tindakan Sementara Untuk Menyelenggarakan Kesatuan Susunan Kekuasaan Dan Acara PengadilanPengadilan Sipil, khususnya Pasal 5 ayat (3) sub b, yang pada intinya memuat tiga hal ${ }^{2}$ :

1. Tindak pidana adat yang tidak ada bandingnya/padanannya dalam KUHP yang sifatnya tidak berat atau yang dianggap tindak pidana adat yang ringan ancaman pidananya adalah pidana penjara paling lama tiga bulan dan/atau denda lima ratus rupiah (setara dengan kejahatan ringan), sedangkan untuk tindak pidana adat yang berat ancaman pidananya paling lama 10 tahun, sebagai pengganti dari hukuman adat yang tidak dijalani oleh terhukum.

2. Tindak pidana adat yang ada bandingannya dalam KUHP, maka ancaman pidananya sama dengan ancaman pidana yang ada dalam KUHP. Misalnya : Tindak Pidana Adat Drati Kerama di Bali yang sebanding dengan zinah menurut Pasal 284 KUHP.

2 Nyoman Serikat Putra Jaya, Hukum (Sanksi) Pidana Adat Dalam Pembaharuan Hukum Pidana Nasional, Masalah - Masalah Hukum, Jilid 45 No. 2, April 2016, hlm. 125 
3. Sanksi adat menurut UU Darurat No.1 Tahun 1951 di atas, dapat dijadikan pidana pokok atau pidana utama oleh hakim dalam memeriksa dan mengadili perbuatan yang menurut hukum yang hidup dianggap sebagai tindak pidana yang tidak ada bandingannya dalam KUHP, sedang yang ada bandingannya harus dikenai sanski sesuai dengan KUHP.

Otje Salman Soemadiningrat sebagaimana dikutip Lilik Mulyadi mengemukakan bahwa hukum pidana adat berikut sanksi-sanksi adat diupayakan untuk dihapus dari sistem hukum di Indonesia dan diganti oleh peraturan perundang-undangan sehingga prosedur penyelesaian perkaraperkara pidana pada umumnya disalurkan melalui peradilan umum. Akan tetapi, kenyataannya sampai sekarang masih terdapat hakim-hakim yang mendasarkan putusannya pada hukum adat atau setidak-tidaknya pada hukum yang dianggap sebagai hukum adat dengan penafsirannya atas dasar Pasal 5 ayat 3 UU No. 1/Drt/1951 ${ }^{3}$. Pengakuan atau pemberian tempat bagi hukum yang hidup atau hukum tidak tertulis sebagai sumber hukum itu, bahkan ditegaskan pula dalam aturan yang bersifat umum, yaitu dalam :

1. Pasal 18 B (2) UUD 1945 (amandemen ke-2). Negara mengakui dan menghormati kesatuan-kesatuan masyarakat hukum adat beserta hak-hak tradisionalnya sepanjang masih hidup dan sesuai dengan perkembangan masyarakat dan prinsip Negara Kesatuan Republik Indonesia, yang diatur dalam undang-undang

2. UU No. 48 Tahun 2009 tentang Kekuasaan Kehakiman.

a. Pasal 5 ayat (1) : Hakim dan Hakim konstitusi wajib menggali, mengikuti, dan memahami nilai-nilai hukum dan rasa keadilan yang hidup dalam masyarakat.

b. Pasal 50 ayat (1) : Putusan pengadilan selain harus memuat alasan dan dasar putusan, juga memuat pasal tertentu dari peraturan perundangundangan yang bersangkutan atau sumber hukum tak tertulis yang dijadikan dasar untuk mengadili.

3. Putusan Mahkamah Agung Republik Indonesia.

a. Putusan Nomor 1644K/Pid/1988 tanggal 15 Mei 1991, antara lain menentukan :

"Seseorang yang telah melakukan perbuatan yang menurut hukum yang hidup (hukum adat) di daerah tersebut adalah merupakan suatu perbuatan yang melanggar hukum adat, yaitu "delict adat". Kepala dan para pemuka adat memberikan reaksi adat (sanksi adat) terhadap si pelaku tersebut. Sanksi adat itu telah dilaksanakan oleh terhukum. Terhadap si terhukum yang sudah dijatuhi "reaksi adat" oleh Kepala Adat tersebut, maka ia tidak dapat diajukan lagi (untuk kedua kalinya) sebagai terdakwa dalam persidangan Badan Peradilan Negara (Pengadilan Negeri) dengan dakwaan yang sama, melanggar hukum adat dan dijatuhi hukuman penjara menurut KUHP (Pasal 5 ayat (3) b Undang-undang Nomor 1 Drt

${ }^{3}$ Lilik Mulyadi, "Eksistensi Hukum Pidana Adat Di Indonesia : Pengkajian Asas, Norma, Teori, Praktik dan Prosedurnya", Jurnal Hukum dan Peradilan, Vol. 2, No. 2, Juli 2013, hlm. 232 
1951). Dalam keadaan yang demikian itu, maka pelimpahan berkas perkara serta tuntutan Kejaksaan di Pengadilan Negeri, harus dinyatakan "tidak dapat diterima" (Niet Ontvakelijk Verklaard)". 4

b. Putusan Nomor 984 K/Pid/1996 tanggal 30 Januari 1996, antara lain berpendirian :

"Perbuatan perselingkuhan suami isteri dengan pihak lain yang selama ini dikenal dengan kualifikasi delik perzinahan ex Pasal 284 KUHP, dan kasus ini ternyata bahwa bilamana si pelaku (dader) telah dijatuhi sanksi adat atau mendapat reaksi adat oleh para pemangku desa adat, dimana hukum adat masih dihormati dan hidup subur di dalam masyarakat adat yang bersangkutan, maka penuntutan jaksa terhadap para pelaku (dader) ex Pasal 284 KUHP secara yuridis harus dinyatakan tidak dapat diterima" .

Dengan demikian Mahkamah Agung mengakui eksistensi hukum pidana adat beserta reaksi adatnya yang masih hidup dalam masyarakat Indonesia.

Diakuinya, hukum pidana adat sesuai dengan ajaran sifat melawan hukum materiil baik dalam fungsinya yang negatif maupun yang positif. Ajaran sifat melawan hukum formil menentukan suatu perbuatan itu melawan hukum apabila bertentangan dengan hukum tertulis atau undang-undang. Ajaran sifat melawan hukum materiil menentukan suatu perbuatan melawan hukum tidak hanya bertentangan dengan hukum tertulis/ undang-undang tetapi juga bertentangan dengan asas-asas hukum yang hidup di dalam masyarakat. Hukum pidana adat termasuk hukum yang hidup atau the living law dapat menjadi : Sumber hukum positif; dan, Sumber hukum yang negatif dalam arti ketentuan-ketentuan hukum pidana adat/the living law dapat menjadi alasan pembenar, memperingan atau alasan memperberat pidana. ${ }^{6}$

Bertitik tolak dari paparan di atas, pertumbuhan hukum pada dasarnya adalah proses yang tidak disadari dan organis. Oleh karena itu, Peraturan perundang-undangan di mata mazhab hukum sejarah adalah kurang penting dibandingkan dengan adat-kebiasaan. Pandangan yang demikian, bisa dipahami mengapa mazhab sejarah kurang menyukai kodifikasi. Kodifikasi hukum selalu membawa efek, yakni menghambat perkembangan hukum, Sejarah berkembang terus, tetapi hukum sudah ditetapkan, maka sama saja menghentikan sejarah hukum pada suatu masa tertentu.

Von Savigny menegaskan inti ajarannya, bahwa hukum itu tidak di buat, tetapi tumbuh dan berkembang bersama masyarakat. Savigny menyatakan bahwa di dunia ini terdapat banyak bangsa, dan tiap-tiap bangsa memiliki suatu 'volksgeist' jiwa rakyat. Jiwa ini berbeda, baik menurut waktu maupun tempat, pencerminannya nampak pada kebudayaan masing-masing yang berbeda-beda, hukum yang bersumber dari jiwa rakyat ini, oleh karena itu hukum itu akan berbeda pada setiap tempat dan waktu, tidaklah masuk akal terdapat hukum

\footnotetext{
${ }^{4}$ Mahkamah Agung, Varia Peradilan, Tahun ke VI, No. 72, September 1991

${ }^{5}$ Mahkamah Agung, Varia Peradilan, Tahun ke XII, No. 151, April 1998

${ }^{6}$ Nyoman Serikat Putra Jaya, hukum ...Op.Cit, hlm 126
} 
yang universal dan abadi. Selanjutnya Von Savigny menyatakan bahwa apa yang menjadi isi hukum itu di tentukan oleh pergaulan hidup manusia dari masa-kemasa, hukum berkembang dari suatu masyarakat sederhana yang tercermin pada setiap tingkah laku individu-individu kepada suatu masyarakat yang kompleks dimana kesadaran hukum masyarakat nampak pada ucapanucapan para ahli hukumnya. Namun dalam ajaran positifistik sumber hukum merupakan norma hasil kesepakatan dari pemegang kekuasaan, diluar itu tidak dianggap sebagai hukum, sementara Von Savigny menyatakan hukum kebiasaan atau hukum adat-lah yang merupakan sumber hukum formal. Hukum tidak dibuat melainkan tumbuh dan berkembang bersama-sama dengan masyarakat. Dalam paham positivisitk baru dikatakan sebagai hukum manakala mendapat sifat deklaratif dari hukum negara, sementara menurut mazhab postivisitk, tanpa di legalisasi oleh negara sekalipun hukum itu tatap berlaku dan sah bagi masyarakat pendukungnya. Theo Hujaiber menyatakan: "Menurut F. von Savigny hukum merupakan salah satu faktor dalam kehidupan bersama suatu bangsa, seperti bahasa, adat, moral, tatanegara. Oleh karena itu hukum adalah sesuatu yang bersidat supra-indiidual, suatu gejala masyarakat. Tetapi suatu masyarakat lahir dalam sejarah. Nyatalah hukum yang termasuk masyarakat itu serta dalam perkembangan organis itu. Lepas dari masyarakat tidak terdapat hukum sama sekali". 7

Apabila dicermati, perbedaan tajam antara mazhab sejarah hukum terhadap positivisme hukum terletak pada sumber dan bentuk hukum. Jika positivisme hukum lebih menekankan hukum pada bentuk formalnya, maka mazhab hukum sejarah berpendapat sebaliknya, tidak hanya penguasa, rakyat yang terdiri dari kompleksitas unsur individu dan kelompok juga mempunyai kekuatan melahirkan hukum. Hukum, menurut mazhab hukum sejarah, bukan diciptakan melainkan ditemukan.

Berdasarkan dari latar belakang tersebut, maka penulis tertarik untuk melakukan penelitian lebih lanjut yang akan dituangkan dalam bentuk penelitian dengan judul "Keberadaan Pidana Adat Dalam Mazhab Sejarah Dihubungkan Dengan Positivisme Hukum".

\section{B. Identifikasi Masalah}

Berdasarkan uraian di atas, pokok permasalahan yang akan dibahas dalam jurnal ini adalah sebagai berikut:

1. Bagaimanakah aksiologi pidana adat dalam positivisme hukum

2. Bagaimanakah konsep eksistensi hukum pidana adat dimasa yang akan datang

\section{Tujuan Penelitian}

Sesuai dengan permasalahan di atas, maka tujuan penelitian ini adalah:

1. Untuk mengetahui Aksiologi pidana adat dalam Positivisme Hukum

2. Untuk merumuskan konsep Esksistensi Hukum pidana Adat dimasa yang

${ }^{7}$ Theo Huijbers, Filsafat Hukum Dalam Lintasan Sejarah, Kanisius, Yogyakarta,1982, hlm. 118 
akan datang

\section{Kerangka Pemikiran}

Fungsi kerangka pemikiran (berpikir) dalam suatu penelitian adalah sebagai tempat yang berisikan pertimbangan-pertimbangan ilmiah terhadap penelitian yang dilaksanakan. Kerangka pemikiran dalam penelitian merupakan tulang punggung penelitian, karena di sini diuraikan landasan-landasan ilmiah atau teori yang digunakan untuk menganalisis temuan penelitian. ${ }^{8}$

Kerangka teori dalam penelitian hukum sangat diperlukan untuk membuat jelas nilai-nilai oleh postulat-postulat hukum sampai kepada landasan filosofisnya yang tertinggi. ${ }^{9}$ Teori hukum sendiri boleh disebut sebagai kelanjutan dari mempelajari hukum positif, setidak-tidaknya dalam urutan yang demikian itulah kita merekonstruksikan kehadiran teori hukum secara jelas. ${ }^{10}$

Sebagai kerangka teori yang akan dibahas dalam tulisan ini salah satunya mengenai teori positivisme hukum. Secara singkat positivisme menurut Herbert Lionel Adolphus Hart, membedakan lima arti dari "positivisme" seperti yang disebut dalam ilmu hukum kontemporer," yaitu ${ }^{11}$ :

1. anggapan bahwa undang-undang adalah perintah-perintah dari manusia (command of human being);

2. anggapan bahwa tidak perlu ada hubungan antara hukum dengan moral atau hukum yang ada dan hukum yang seharusnya ada;

3. anggapan bahwa analisa (studi tentang arti) dari konsepsi-konspesi hukum :

a) layak dilanjutkan,

b) harus dibedakan dari penelitian-penelitian histories mengenai sesbab sebab atau asal-usul undang-undang dari penelitian sosiologis mengenai hubungan hukum dengan gejala sosial lainnya, dan kritik atau penghargaan hukum apakah dalam arti moral, tuntutan sosial, fungsifungsinya, atau sebaliknya;

4. anggapan bahwa sistem hukum adalah suatu "sistem logis tertutup" dimana putusan-putusan hukum yang tepat dapat dihasilkan dengan cara yang logis dari peraturan-peraturan hukum yang telah ditentukan terlebih dahulu tanpa mengingat tuntutan sosial, kebijaksanaan, norma-norma moral,

5. anggapan bahwa penilaian-penilaian moral tidak dapat diberikan atau dipertahankan. Misalnya, Pernyataan tentang fakta, dengan alasan yang rasional, petunjuk, atau bukti. (non-cognitivisme dalam etika).

Berdasarkan pemikiran-pemikiran para eksponen positivisme tersebut, pada hakekatnya; dilihat dari bentuknya, teori positivisme hukum memandang

8 Sugiyono, Metode Penelitian Kuantitatif, Kualitatif dan $R$ \& $D$, Cetakan Kesembilan, Alfabeta,Bandung, 2010, hlm. 60. Lihat juga Uma Sekaran, Research Methods for Business, A Skill-Building Approach, Illionis: Southern Illionis University at Carbondale (SIUC), 1984, p. 80.

${ }^{9}$ Satjipto Rahardjo, llmu Hukum, P.T. Citra Aditya Bakti, Bandung, 1991, hlm. 254.

${ }^{10}$ Ibid, hlm. 253

11 W. Friedman., Teori dan Filsafat Hukum, Telaah Kritis atasTeori-teori Hukum (susunan I), diterjemahkan dari buku aslinya "Legal Theory" oleh Mohamad Arifin., Rajawali, Jakarta., 1990., hal 147. 
bahwa hukum adalah Undang-undang, dilihat dari isinya, hukum adalah perintah dari penguasa; maka terdapat otoritas penguasa yang membentuk undang-undang. Dalam teori ini, keadilan bukanlah unsur dalam hukum. Keadilan dipandang sebagai unsur regulative, bukan unsur konstitutif. Hukum yang tidak memenuhi rasa keadilan tetap disebut hukum, walaupun merupakan hukum yang buruk.

Di era Negara Proklamasi Kemerdekaan Republik Indonesia, dan dengan ditetapkannya UUD 45 sebagai Undang-Undang Dasar atau hukum dasar tertulis (constitusi) pada tanggal 18 Agustus 1945, warna positivisme hukum tetap melekat. Pasal I Aturan Peralihan UUD 45 (amandemen ke-4), yang menyatakan bahwa segala peraturan perundang-undangan yang ada masih tetap berlaku selama belum diadakan yang baru menurut Undang-Undang Dasar ini.

Seluruh peraturan hukum produk Hindia Belanda masih tetap berlaku, hal ini bertujuan agar selama masa transisi, jangan sampai terjadi kekosongan hukum, namun akibat negatifnya, selain berlangsung masa transisi tanpa batas, maka juga secara tidak sadar melanggengkan paradigma Hukum Barat yang positivistis. Menurut Ahmad $\mathrm{Ali}^{12}$, seyogyanya ketika berlangsung amandemen UUD ${ }^{c 45}$, dicantumkan pembatasan masa berlakunya Aturan Peralihan, misalnya paling lama 10 tahun sejak UUD ${ }^{\text {ee }} 4$ diamandemen terakhir.

Selain teori positivisme hukum akan digunakan pula aliran atau Madzab Sejarah. Inti ajaran Madzab Sejarah yang didirikan oleh Savigny ini terdapat dalam bukunya 'von Beruf Ungerer Zeit fur Gesetzgebung und Rechtswissenschaft (Tentang Tugas Zaman Kita Bagi Pembentuk Undangundang dan Ilmu Hukum). antara lain dikatakan ${ }^{13}$ : 'Das Recht wird nicht gemacht. est ist und wird mit dem volke (Hukum itu tidak dibuat. tetapi tumbuh dan berkembang bersama masyarakat).

Ajaran Savigny tersebut dilatarbelakangi oleh suatu pandangannya yang mengatakan bahwa didunia ini terdapat banyak bangsa dan pada tiap bangsa mempunyai Volkgeist/jiwa rakyat. Perbedaan ini juga sudah barang tentu berdampak pada perbedaan hukum yang disesuaikan dengan tempat dan waktu. Hukum sangat bergantung atau bersumber pada jiwa rakyat dan isi hukum itu ditentukan oleh pergaulan hidup manusia dari masa ke masa.

Hukum menurut pendapat Savigny berkembang dari suatu masyarakat yang sederhana yang pencerminannya tampak dalam tingkah laku semua individu kepada masyarakat yang modern dan kompleks dimana kesadaran hukum rakyat itu tampak pada apa yang diucapkan oleh para ahli hukumnya. ${ }^{14}$

12 Achmad Ali., Menguak Teori Hukum (Legal Theory) dan Teori Peradilan (Judicialprudence)., Kencana Prenada Group, Jakarta, 2009. Hlm. 6

13 Lili Rasjidi, Dasar-dasar Filsafat Hukum, cet. VII, Citra Aditya Bakti, 1996, Bandung, hlm. 69.

${ }^{14} \mathrm{Ibid}$, hlm 65 
Pokok-pokok ajaran madzab historis yang diuraikan Savigny dan beberapa pengikutnya dapat disimpulkan sebagai berikut ${ }^{15}$ :

1. Hukum ditemukan tidak dibuat ${ }^{16}$. Pertumbuhan hukum pada dasarnya adalah proses yang tidak disadari dan organis;oleh karena itu perundangundangan adalah kurang penting dibandingkan dengan adat kebiasaan.

2. Karena hukum berkembang dari hubungan-hubungan hukum yang mudah dipahami dalam masyarakat primitif ke hukum yang lebih kompleks dalam peradaban modern kesadaran umum tidak dapat lebih lama lagi menonjolkan dirinya secara langsung, tetapi disajikan oleh para ahli hukum yang merumuskan prinsip-prinsip hukum secara teknis. Tetapi ahli hukum tetap merupakan suatu organ dari kesadaran umum terikat pada tugas untuk memberi bentuk pada apa yang ia temukan sebagai bahan mentah (Kesadaran umum ini tampaknya oleh Scholten disebut sebagai kesadaran hukum). Perundang-undangan menyusul pada tingkat akhir; oleh karena ahli hukum sebagai pembuat undang-undang relatif lebih penting daripada pembuat undang-undang.

3. Undang-undang tidak dapat berlaku atau diterapkan secara universal. Setiap masyarakat mengembangkan kebiasaannya sendiri karena mempunyai bahasa adat-istiadat dan konstitusi yang khas. Savigny menekankan bahwa bahasa dan hukum adalah sejajar juga tidak dapat diterapkan pada masyarakat lain dan daerah-daerah lain. Volkgeist dapat dilihat dalam hukumnya oleh karena itu sangat penting untuk mengikuti evolusi volkgeist melalui penelitian hukum sepanjang sejarah.

Di Indonesia pengaruh ajaran madzab sejarah sangat dirasakan, yakni dengan lahirnya cabang ilmu hukum baru yang dikenal sebagai hukum adat, yang dipelopori oleh Van Vollenhoven, Ter Haar serta tokoh-tokoh hukum adat lainnya. Demikian juga bagi para ahli sosiologi, saran Savigny memperteguh keyakinan mereka bahwa antara sistem hukum dan sistem sosial lainnya terdapat hubungan timbal balik yang saling mempengaruhi. Keyakinan semacam itu akan menghasilkan suatu produk hukum yang akan memiliki daya berlaku sosiologis.

Mochtar Kusumaatmadja mengatakan bahwa bagi Indonesia, pemikiran dan sikap madzab ini terhadap hukum telah memainkan peranan yang penting dalam mempertahankan ("preservation") hukum adat sebagai pencerminan dari nilai-nilai kebudayaan (asli) penduduk pribumi dan mencegah terjadinya "pembaratan" (westernisasi) yang terlalu cepat, kalau tidak hendak dikatakan

15 W. Friedmann, Legal Teori, alih bahsa Mohammad Arifin, Teori dan Filsafat Hukum : Idealisme Filosofis dan Problem Keadilan, cet. I (Jakarta, CV. Rajawali, 1990), hlm. 61

${ }^{16}$ Implikasi dari ajaran Savigni ini adalah penolakannya terhadap pengagungan akal seseorang. Cara pandang ini yang membedakan kaum realis dengan aliran historis. Kaum realis lebih mengedepankan prediksi waktu yang akan datang sedangkan aliran historis dianggap telah melakukan kesalahan karena terlalu mengagung-agungkan masa lampau. Ketidak percayaan terhadap pembuatan undang-undang terutama yang terkodifikasi menunjukkan adanya pandangan yang skeptis terhadap kemauan manusia dan meragukan keberhasilan manusia untuk menguasai dunianya Satjipto Rahardjo, Ilmu Hukum, Citra Aditya Bakti, Bandung, 1991, hlm. 277. bandingkan dengan Teo Huijbers, Op.Cit., hlm 279 
berhasil mencegahnya sama sekali, kecuali bagi sebagian kecil golongan pribumi $^{17}$.

Dalam konteks kekinian, lahirnya gerakan pemikiran hukum yang mengarah pada pengoptimalisasian fungsi lembaga mediasi yang ada dilevel masyarakat grass root secara tidak langsung dapat dikatakan sebagai pengaruh tidak langsung mazhab sejarah bagi pemikiran hukum di Indonesia. Di Nusa Tenggara Barat gerakan ini mulai diawali di desa Lebah Sempaga dan Desa Bagu yang telah membuat Balai Mediasi Desa yang sudah mengarah kepada penggalian budaya dan kebiasaan masyarakat.

\section{E. Metode Penelitian}

Jenis penelitian yang digunakan dalam penelitian ini adalah penelitian yuridis normatif yang mencakup penelitian terhadap asas-asas hukum, sistematika hukum, sinkronisasi hukum dan sejarah hukum. Penelitian yuridis normatif diambil sebagai pendekatan utama dalam penelitian ini karena yang menjadi fokus utama adalah ketentuan-ketentuan yang mengatur tentang keberadaan pidana adat dalam mazhab sejarah dan pengaturan hukum pidana adat dalam positivisme hukum.

Penelitian yuridis normatif disebut juga penelitian hukum doktrinal. ${ }^{18}$ Dimana hukum dikonsepsikan sebagai apa yang tertulis dalam peraturan perundang-undangan (law in books) atau hukum yang dikonsepsikan sebagai kaidah atau norma yang merupakan patokan berprilaku masyarakat terhadap apa yang dianggap pantas.

Berdasarkan tipe penelitian yuridis normatif tersebut di atas, maka pendekatan yang digunakan dalam penelitian ini adalah pendekatan perundangundangan (normative approach), pendekatan sejarah (historial approach), pendekatan konseptua (conceptual aproach) ${ }^{19}$

Pendekatan perundang-undangan dilakukan dengan meneliti formulasi ketentuan yang mengatur tentang hukum pidana adat di dalam perundangundangan Indonesia baik berupa hukum positif, maupun masih berbentuk rancangan. Pendekatan sejarah dilakukan dengan meneliti sejarah politik yang berkaitan dengan hukum pidana adat Indonesia dari berbagai literatur yang ada. Pendekatan konsptual adalah dengan meneliti dan memasukkan konsep-konsep mengenai politik hukum yang berkaitan dengan hukum pidana adat.

Pengumpulan bahan hukum dilakukan dengan sistem kartu (card system) melalui berbagai sumber, yang terdiri dari:

1. Bahan hukum primer, diantaranya meliputi Undang-Undang Dasar Negara Republik Indonesia Tahun 1945, Kitab Undang-Undang Hukum Pidana (KUHP), Undang-Undang Republik Indonesia Nomor 8 Tahun 1981 tentang Kitab Undang-undang Hukum Acara Pidana (KUHAP), UndangUndang

\footnotetext{
${ }^{17}$ Zulkarnain, Kritik Terhadap Pemikiran Hukum Madzab Sejarah, Digitized by USU digital library, 2003, hlm 7

18 Jonaedi Efendi, Johnny Ibrahim, Metode Penelitian Hukum Normatif dan Empiris, Prenadamedia Group, Depok, 2018, hlm. 124

19 Johnny Ibrahim, Teori dan Metodologi Penelitian Hukum Normatif, Bayumedia Publishing, Cet. IV, Malang, 2008, hlm. 302.
} 
Nomor 48 Tahun 2009 tentang Kekuasaan Kehakiman. Undang-Undang Nomor 16 Tahun 2004 tentang Kejaksaan Republik Indonesia.

2. Bahan hukum sekunder, meliputi rancangan undang-undang, yurisprudensi, buku-buku literatur yang berhubungan dengan hukum adat, hasil seminar, makalah-makalah, jurnal, majalah hukum dan naskah lain yang mempunyai relevansi dengan objek yang diteliti.

3. Bahan hukum tertier, meliputi kasus hukum, ensiklopedia dan tulisan non hukum lainnya yang berkaitan dengan masalah yang diteliti.

Guna lebih mempermudah pembahasan, maka informasi yang didapat dan diperoleh selanjutnya dihimpun melalui proses yang bertahap. Berawal dari sumber-sumber yang tertulis yang berasal dari peraturan perundangundangan dan tulisan-tulisan lain yang berhubungan dengan inti permasalahan. Selanjutnya bahan-bahan hukum yang sudah berhasil dikumpulkan diolah sesuai dengan keperluan untuk dijadikan bahan pembahasan dengan jalan menghimpun dan mengklasifikasikannya dalam masing-masing bab dan sub bab yang telah disusun berurutan menurut pokok permasalahan untuk kemudian dianalisis.

Bahan-bahan hukum yang sudah dikumpulkan tersebut dianalisis dengan berpedoman pada metode kualitatif, yaitu suatu cara penelitian yang menghasilkan informasi deskriptif analitis, dan terkumpul untuk kemudian menguraikan fakta yang telah ada dalam jurnal ini kemudian ditarik suatu kesimpulan dan saran dengan memanfaatkan cara berpikir deduktif yaitu menarik kesimpulan yang berangkat dari hal-hal yang bersifat umum menuju hal-hal yang bersifat khusus.

\section{F. Hasil Penelitian dan Pembahasan}

\section{Aksiologi Pidana Adat Dalam Positivisme Hukum}

Aksiologi mempelajari nilai yang hendak dituju dari suatu ilmu. Dengan kata lain, pertanyaan mendasar mengenai aspek aksiologis suatu ilmu adalah untuk apa ilmu pengetahuan itu dibangun dan dikembangkan? Dalam konteks hukum, aksiologi terkait tujuan atau nilai-nilai tertentu yang hendak dituju dari suatu hukum, seperti tujuan hukum adalah untuk mencapai keadilan hukum, kemanfaatan hukum atau kepastian hukum ${ }^{20}$.

Positivisme merupakan aliran pemikiran yang mendasar pada pengalaman empirik bukan pada keyakinan, dan segala gejala dapat dikatakan benar apabila telah dilakukan verifikasi secara berulang dan

${ }^{20}$ Mahrus Ali, Fondasi Ilmu Hukum Berketuhanan: Analisis Filosofis terhadap Ontologi, Epistemologi, dan Aksiologi, https://journal.unnes.ac.id/nju/index.php/ pandecta/ article/ view/7844. Dikases pada tanggal 25/02/2020 
hasilnya sama ${ }^{21}$. Adji Samekto dalam bukunya menyimpulkan bahwa inti dari ajaran filsafat positivisme adalah: ${ }^{22}$

a. Positivisme bertolak dari pandangan bahwa filsafat positivisme hanya mendasarkan pada kenyataan (realita, fakta) dan bukti terlebih dahulu;

b. Positivisme tidak akan bersifat metafisik, dan tidak menjelaskan tentang esensi;

c. Positivisme tidak lagi menjelaskan gejala-gejala alam sebagai ide abstrak. Gejala alam diterangkan berbasis hubungan sebab-akibat dan dari itu kemudian didapatkan dalil-dalil atau hukum-hukum yang tidak tergantung dari ruang dan waktu;

d. Positivisme menempatkan fenomena yang dikaji sebagai objek yang dapat digeneralisasi sehingga ke depan dapat diramalkan (diprediksi);

e. Positivisme meyakini bahwa relaitas (gejala) dapat direduksi menjadi unsur-unsur yang saling terkait membentuk sistem yang dapat diamati.

Dalam perkembangannya, muncul aliran pemikiran hukum yang bersumber dari filsafat positivisme biasa disebut dengan legal positivism. Legal positivism mengkonsepsikan hukum sebagai ketentuan-ketentuan yang berlaku mengikat masyarakat karena dikeluarkan oleh kekuasaan yang paling tinggi, mengandung perintah dan sanksi ${ }^{23}$

Aksiologi positivisme telah melahirkan hukum dalam skesta matematika, menyelesaikan hukum yang terjadi dalam masyarakat berdasar apa yang tertulis dalam teks undang-undang, mengkristal di posisi binernya suatu teks lalu pembaca harus memahami di keadaan itu dan tidak dibolehkan untuk berpikir lain. Sementara para hakim memutus perkara dengan teks tersebut atas persoalan hukum yang dihadapi. Seperti halnya yang terjadi di Indonesia, hakim memutus perkara mengutamakan hukum tertulis sebagai sumber utamanya. Kelompok-kelompok hakim yang berpikir demikian dapat digolongkan sebagai suatu aliran konservatif. $^{24}$ Produk hukum sendiri akan melahirkan formalistik semata di mana kepastian hukum menjadi ikon kebenaran. Keadilan adalah keadilan yang terdefinisi atas apa yang tertulis dan menutup diri atas keadilan yang selama ini tidak termaktub dalam suatu teks perundang-undangan. Teori ini mengidentikkan hukum dengan undang-undang. Tidak ada hukum di luar undang-undang dan satu-satunya hukum adalah undang-undang. ${ }^{25}$

${ }^{21}$ Odie Faiz Guslan, dominasi positivisme hukum dan eksistensi hukum adat dalam sistem hukum nasional https://rechtsvinding.bphn.go.id/jurnalonline/edit\%20 Naskah\% 20 JRV\%20Online\%20DOMINASI\%20POSITIVISME\%20HUKUM\%20DAN\%20EKSISTE NSI\%20HUKUM\%20ADAT\%20DALAM\%20SISTEM\%20HUKUM\%20NASIONAL.pd f. . Dikases pada tanggal 25/02/2020

23 Ibid

$$
{ }^{22} \text { Ibid }
$$

${ }^{24}$ Lintong O. Siahaan, "Peran Hakim Dalam Pembaharuan Hukum di Indonesia", Jurnal Hukum dan Pembangunan, Tahun ke 36 N0.1 Januari 2006, Fakultas Hukum Universitas Indonesia, Jakarta, 2006 hlm. 35

${ }^{25}$ Rusli Muhammad, "Kajian Kritis Terhadap Teori Hukum Positif (Positivisme)", Jurnal Hukum Respublica, Vol. 5, No. 2, Tahun 2006, Fakultas Hukum Universitas Lancang Kuning (Unilak), Pekanbaru, 2006, hlm. 222-223 
Aliran positivisme hukum di Indonesia tumbuh dengan subur sebagai implikasi dari negara Indonesia merupakan jajahan dari negara Belanda yang menganut tradisi civil law system. Dalam tradisi civil law memiliki ciri khas yang begitu menonjol, yaitu dalam hal kepastian hukum (legal certainity). Untuk menjamin adanya kepastian hukum maka dalam civil law system sangat mengandalkan dilakukannya kodifikasi atau himpunan peraturan hukum yang dilakukan secara tertulis (lex scripta). Adanya peraturan hukum yang telah dituangakan secara tertulis tersebut, dipergunakan untuk memastikan dan menjamin prediktabilitas, supaya orang tidak melakukan perbuatan di luar apa yang telah ditentukan oleh pembentuk peraturan.

Tradisi civil law yang kental akan nuansa positivisme menyebabkan para penegak hukum, para pembentuk undang-undang dan para sarjana hukum terutama di Indonesia dewasa ini dalam melaksanakan tugastugasnya terkesan sangat kaku karena hanya mengandalkan rule and logic dan memarginalkan aspek behaviour, value and the truth ${ }^{26}$. Mereka sangat mengedepankan kepastian hukum namun disisi lain seringkali mereka lupa, bahwa dalam tataran implementasi yang diterapkan tidak hanya kepastian hukum saja, namun juga "kepastian hukum yang adil". Tidak hanya sebagai corong undang-undang saja, namun para penegak hukum dan sarjana hukum juga dituntut untuk dapat melihat bagaimana realitas di lapangan jadi keadilan yang diterapkan tidak hanya keadilan formal saja namun juga keadilan secara substantif. Disamping adanya pewarisan tradisi civil law yang ditinggalkan bangsa Belanda, Indonesia juga mewarisi nilai-nilai hukum lain yang berasal dari masyarakat Indonesia itu sendiri. Karena pada dasarnya negara Indonesia termasuk ke dalam golongan traditional and religious law system.

Indonesia termasuk kedalam golongan traditional and religious law system, dikarenakan negara Indonesia dikenal sebagai negara yang bercorak multikulutral, agama, ras, dan terdiri dari banyak golongan dan dimana tiaptiap daerah memiliki masyarakat dan budaya hukum yang berbeda-beda. Sesuai dengan dasar negara kita Pancasila dengan semboyannya, yaitu bhinneka tunggal ika yang berarti Indonesia adalah negara dengan segala kemajemukannya namun tetap dalam Negara Kesatuan Republik Indonesia. Berdasarkan uraian tersebut, selain terdapat peraturan hukum yang tertulis, di Indonesia terdapat juga peraturan hukum yang tidak tertulis sesuai dengan corak, kultur masyarakat. Hal ini biasa disebut dengan hukum adat (hukum pidana adat) atau hukum yang bersumber dari suatu kebiasaan masyarakat (adatrecht, the living law, the unwritten law, customary law).

Pidana adat yang ada di Indonesia memiliki tujuan/nilai-nilai tertentu yang hendak dicapai yang berbeda dengan tujuan/nilai-nilai dalam aliranaliran filsafat hukum yang lahir di dunia barat dan untuk mengetahui dan menemukan nilai-nilai aksiologis pidana adat adalah dengan memahami dan menggali nilai-nilai yang hidup dalam masyarakat adat setempat, namun

${ }^{26}$ Odie Faiz Guslan, dominasi...Op.Cit, hlm 36 
dalam positivisme hukum, pidana adat yang tidak tertulis atau hukum yang hidup dalam masyarakat sama sekali tidak mempunyai tempat sebagai sumber hukum yang positif. Hal ini diungkapkan pula dalam bagian pidato pengukuhan guru besarnya Barda Nawawi Arief berpendapat bahwa : "Terlebih dengan adanya perumusan asas legalitas yang formal di dalam Pasal 1 KUHP, hukum tidak tertulis atau hukum yang hidup dalam masyarakat sama sekali tidak mempunyai tempat sebagai sumber hukum yang positif. Dengan perkataan lain, dengan adanya Pasal 1 KUHP itu seolah-oleh hukum pidana adat tidak tertulis yang hidup atau yang pernah ada di masyarakat, sengaja ditidurkan atau dimatikan".

Dominasi KUHP sebagai representasi Hukum Barat yang dibawa Belanda, seiring dengan lamanya waktu penjajahan Belanda terhadap Indonesia, telah terjadi transformasi sistem hukum dan nilai sosial masyarakat, yang secara langsung telah meminggirkan keberadaan hukum pidana adat. Dominasi Hukum Barat menguasai pengaturan kehidupan masyarakat, baik dibidang publik maupun privat. Secara mutatis mutandis pemberlakuan Hukum Barat tersebut telah terjadi pemaksaan sistem nilai Barat terhadap sistem nilai masyarakat Indonesia, yang antara keduanya merupakan sistem nilai yang berlainan. Namun meskipun KUHP dan undang-undang pidana di luar KUHP telah mendominasi dan secara formal merupakan hukum positif yang berlaku dalam menyelesaiakan segala perkara pidana, tidak dapat dipungkiri bahwa hukum pidana adat sebagai hukum yang tidak tertulis, juga mendapat tempat dalam arti dipraktekkan dan dipakai penyelesian dalam menangani pelanggaran tindak pidana adat, meskipun tidak berkembang.

Hukum Pidana Adat sebagai hukum yang hidup (living law), adalah realitas yang tidak dapat dihilangkan atau dimatikan. Hukum Pidana Adat menyangkut cita sosial dan keadilan masyarakat, ia menjadi darah dan daging dalam kehidupan masyarakat, Hukum Pidana Adat merupakan hukum asli yang berasal dan berkembang dari Bangsa Indonesia yang sudah ada sejak lama. Hukum Pidana Adat berkembang dengan cara turun temurun dari satu generasi ke generasi berikutnya dalam masyarakat adat yang mendapat pengaruh dari adanya berbagai agama maupun perkembangan zaman. Demikian mengenai adanya hukum yang berasal dari masyarakat juga dibenarkan oleh Van Vollenhoven seperti yang dijelaskan oleh R.Otje Salman Soemadiningrat ${ }^{27}$, adalah sebagai berikut:

"Van Vollenhoven dalam penelitian pustakanya pernah menyatakan bahwa masyarakatmasyarakat asli yang hidup di Indonesia, sejak ratusan tahun sebelum kedatangan Bangsa Belanda, telah memiliki dan hidup dalam tata hukumnya sendiri. Tata hukum masyarakat asli tersebut dikenal dengan sebutan Hukum Adat”.

27 Galuh Faradhilah Yuni Astuti, Relevansi Hukum Pidana Adat Dalam Pembaharuan Hukum Pidana di Indonesia https:// journal. unnes.ac. id/nju/index.php/ pandecta/ article/ download/ 4953/4102, diakses pada tanggal 25/02/2020 
Mengenai hukum Adat sampai dewasa ini masih sangat kuat pengaruhnya terhadap praktik hukum dan kenegaraan kita ${ }^{28}$. Hal ini dapat dilihat pada bagaimana praktik-praktik hukum di dalam administrasi dan pengadilan-pengadilan. Di dalam lingkungan kenegaraan pun sangat terasa pengaruh dan bekerjanya Hukum Adat. Misalnya dalam menerapkan ketentuan-ketentuan Undang-Undang Dasar 1945 yaitu dalam soal musyawarah, mufakat dan sebagainya. Untuk mengangkat, mengembangkan dan menggali aksiologi nilai-nilai hukum pidana adat sebagai intrumen pelembagaan hukum pidana adat, dalam kehidupan hukum di Indonesia, dapat di inventarisir melalui 3 (tiga) pintu atau jalur. Ketiga jalur tersebut adalah melalui jalur peradilan, jalur legisiasi dan jalur akademik.

Pelembagaan hukum pidana adat melalui jalur peradilan, menggunakan "pintu" masuk melalui Undang-Undang No. 1 Drt/1951 tentang tindakan sementara untuk Menyelenggarakan Kesatuan Sususnan Kekuasaan dan Acara Pengadilan-pengadilan Sipil, khususnya ketentuan Pasal 5 ayat (3) sub b. Dari ketentuan Pasal (asas legalitas formal.) tidak mengurangi berlakunya hukum yang hidup dalam masyarakat yang menentukan bahwa seorang patut dipidana walaupun perbuatan tersebut tidak diatur dalam peraturan perundang-undangan." Sedangkan Pasal 1 ayat (4) berbunyi "berlakunya hukum yang hidup dalam masyarakat sebagaimana dimaksud pada ayat (3) sepanjang sesuai dengan nilai-nilai Pancasila dan/atau prinsip-prinsip hukum umum yang diakui oleh masyarakat bangsa-bangsa." Ketentuan tersebut menunjukkan adanya perluasan asas legalitas, yaitu disamping asas legalitas formil (Pasal 1 ayat (1) konsep) diakui juga asas legalitas materiil, yang bersumber dari ketentuan hukum yang hidup (the living law) sebagai landasan hukum. Diakuinya hukum pidana adat tersebut sesuai dengan ajaran sifat melawan hukum materiil, baik dalam fungsinya yang positif maupun negatif. Dalam fungsinya yang positif, suatu perbuatan dianggap tetap menjadi suatu tindak pidana meskipun tidak nyata diancam dengan pidana oleh undang-undang, asalkan menurut hukum yang hidup dianggap sebagai tindak pidana. Dalam hal ini aksiologi hukum pidana adat menjadi sumber hukum yang positif. Sebaliknya dalam fungsinya yang negatif, hukum pidana adat menjadi sumber hukum yang negatif dalam arti ketentuan-ketentuan hukum pidana adat bisa menjadi alasan pembenar, alasan meringankan pidana atau alasan memperberat pidana. Disamping secara tegas hukum pidana adat diberi ruang sebagai salah satu sumber hukum, dalam penyusunan Konsep KUHP Nasional yang tercermin dalam rumusan tindak pidana, tujuan pemidanaan, ketentuan sanksi dan penentuan kebijakan hukum pidana lainnya juga menyerap dan mengadaptasi asas-asas dan sistem nilai yang bersumber dari ketentuan hukum yang hidup (hukum pidana adat).

Pelembagaan hukum pidana adat dalam kasanah kehidupan hukum pidana nasional juga muncul dari kegiatan-kegiatan yang bersifat ilmiah dan

${ }^{28}$ Hadikusuma, Pengantar Ilmu Hukum Adat Indonesia. Mandar Maju, Bandung, 2003.hlm 31 
akademis (keilmuan), mulai dari kegiatan seminar, symposium dan lokakarya nasional tentang hukum pidana, maupun pengajaran secara terstruktur matakuliah Hukum Pidana Adat diperguruan tinggi, khususnya fakultas hukum.

\section{Konsep Eksistensi Hukum Pidana Adat Di masa Yang Akan Datang}

Eksistensi hukum pidana adat tersebut dapat dikatakan antara "ada" dan "tiada". Ada 2 (dua) argumentasi yang patut dikemukakan dalam konteks ini mengapa kajian terhadap hukum pidana adat diasumsikan eksistensinya antara ada dan tiada ${ }^{29}$.

Pertama, dikaji dari dimensi asas legalitas formal (selanjutnya disebut sebagai asas legalitas) dan asas legalitas materiil. Pada dasarnya asas legalitas lazim disebut dengan terminologi "principle of legality", "legaliteitbeginsel", "non-retroaktif", "de la legalite" atau "ex post facto laws". Ketentuan asas legalitas diatur dalam Pasal 1 ayat (1) KUHP Indonesia yang berbunyi: Tiada suatu peristiwa dapat dipidana selain dari kekuatan ketentuan undang-undang pidana yang mendahuluinya. (Geen feit is strafbaar dan uit kracht van een daaran voorafgegane wetteljke strafbepaling).

Dikaji dari perspektif sejarah terbentuknya asas legalitas dalam KUHP Indonesia berasal dari Wetboek van Strafrecht Nederland (WvS. Ned), sebagaimana berasal dari ketentuan Pasal 8 Declaration des Droits De L"Homme Et Du Citoyen tahun 1789 yang berbunyi, tidak ada orang yang dapat dipidana selain atas kekuatan undang-undang yang sudah ada sebelumnya dan merupakan pandangan Lafayette dari Amerika ke Perancis dan bersumber dari Bill of Rights Virgina tahun 177.

Dari dimensi konteks di atas, nyatalah bahwa asas legalitas lahir, tumbuh dan berkembang dalam alam liberalisme. Akan tetapi pada dimensi kekinian ternyata alam liberalisme tersebut relatif kurang cocok diterapkan dalam kondisi masyarakat Indonesia yang bersifat pluralistis sehingga konsekuensi logisnya perlu dicari suatu formula berupa adanya keinginan untuk menerapkan keseimbangan monodualistik antara asas legalitas formal dan asas legalitas materiil. ${ }^{30}$ Eksistensi asas legalitas materiil sebagaimana dikaji dari perspektif ius constituendum diatur dalam ketentuan Pasal 2 ayat (1) RUU KUHP Tahun 2012 yang berbunyi sebagai berikut: Ketentuan sebagaimana dimaksud dalam Pasal 1 ayat (1) tidak mengurangi berlakunya hukum yang hidup dalam masyarakat yang menentukan bahwa seseorang patut dipidana walaupun perbuatan tersebut tidak diatur dalam peraturan perundangundangan.

Apabila dipadankan asas legalitas formal dan materiil hendaknya diatur dalam peraturan perundang-undangan dan diimplementasikan secara integral. Pada asas legalitas dasar patut dipidana suatu perbuatan adalah undang-undang yang sudah ada sebelum perbuatan tersebut dilakukan. Kemudian asas legalitas materiel menentukan bahwa dasar patut dipidana suatu perbuatan adalah

\footnotetext{
${ }^{29}$ Lilik Mulyadi, Eksistensi Hukum Pidana ...Op.Cit , hlm 235

${ }^{30}$ Ibid, hlm 236
} 
hukum yang hidup dalam masyarakat yaitu hukum tidak tertulis atau hukum adat. Barda Nawawi Arief menyebutkan dengan adanya perumusan asas legalitas yang formal di dalam Pasal 1 KUHP, hukum tidak tertulis atau hukum yang hidup di dalam masyarakat sama sekali tidak mempunyai tempat sebagai sumber hukum yang positif. Dengan perkata lain, adanya Pasal 1 KUHP itu seolah-olah hukum pidana tidak tertulis yang hidup atau pernah ada di masyarakat, sering ditidurkan atau dimatikan. Semasa zaman penjajahan, ditidurkannya hukum pidana tidak tertulis itu masih dapat dimaklumi karena memang sesuai dengan politik hukum Belanda pada saat itu. Namun, akan dirasakan lain apabila kebijakan itu juga diteruskan seusai kemerdekaan. Dengan adanya Pasal 1 KUHP, hukum tidak tertulis / hukum yang hidup itu tidak pernah tergali dan terungkap secara utuh kepermukaan, khususnya dalam praktek peradilan pidana maupun dalam kajian akademik di perguruan tinggi. Selanjutnya, berarti tidak pernah berkembang dengan baik tradisi yurisprudensi maupun tradisi akademik / keilmuan mengenai hukum pidana tidak tertulis itu. Kalau toh ada, hanya dalam ruang yang sangat terbatas dan (sekali lagi) tidak utuh atau tidak lengkap. ${ }^{31}$

Konklusi dasar dari apa yang diterangkan di atas menyebutkan asas legalitas sebagaimana ketentuan Pasal 1 KUHP memang merupakan salah satu asas fundamental yang harus tetap dipertahankan, namun penggunaan harus dengan bijaksana dan hati-hati, karena kalau kurang bijaksana dan kurang hatihati, justru dapat menjadi bumerang. Sungguh sangat tragis dan menyayat hati apabila dengan dalih Pasal 1 KUHP, nilai-nilai hukum yang ada dan hidup dalam masyarakat tidak dapat tersalur dengan baik atau bahkan ditolak sama sekali. Dikatakan tragis dan menyayat hati karena berarti nilai-nilai hukum adat/hukum yang hidup di dalam masyarakat telah dibunuh/dimatikan oleh bangsanya sendiri lewat senjata/peluru/pisau yang diperoleh dari bekas penjajah (yaitu lewat Pasal $1 \mathrm{KUHP} / \mathrm{WvS}$ ). ${ }^{32}$

Kedua, dikaji dari perspektif UU Nomor 1 dart Tahun 1951 dimana dalam ketentuan Pasal 5 ayat (3) sub b masih dikenal eksistensinya Pengadilan Adat. Akan tetapi, setelah dikodefikasikan Undang-Undang tentang KetentuanKetentuan Pokok Kekuasaan Kehakiman (Pasal 10 UU Nomor 14 Tahun 1970), yang kemudian dirubah dengan UU Kekuasaan Kehakiman (UU Nomor 35 Tahun 1999, UU Nomor 4 Tahun 2004, UU Nomor 48 Tahun 2009) tidak dikenal lagi eksitensi Pengadilan Adat dalam tataran kebijakan legislasi walaupun untuk daerah Aceh Nangroe Darussalam sebagaimana UU Nomor 11 Tahun 2006 tentang Pemerintahan Aceh eksistensi Pengadilan Adat masih diterapkan dan dikenal dengan istilah Peradilan Gampong atau Peradilan Damai. Akan tetapi walaupun kebijakan formulatif sejak UU 14 Tahun 1970 (berikut UU Nomor 35 Tahun 1999, UU Nomor 4 Tahun 2004, UU Nomor 48 Tahun 2009) yang tidak mengakui eksistensi peradilan adat fakta aktual dalam

31 Barda Nawawi Arief, Beberapa Aspek Pengembangan Ilmu Hukum Pidana (Menyongsong Generasi Baru Hukum Pidana Indonesia), Pidana Pengukuhan Guru Besar, Fakultas Hukum Universitas Diponegoro, Semarang, 1994, hlm. 25

32 Surojo Wignjodipuro, Pengantar dan Azas-Azas Hukum Adat, Alumni, Bandung, 1979, hlm. 298 
kebijakan aplikatif baik dikaji dari praktik di yudex facti (Pengadilan Negeri) dan yudex yuris (Mahkamah Agung) melalui yurisprudensi eksistensi peradilan adat tetap mengakuinya ${ }^{33}$. Misalnya, sebagai salah satu contohnya pada Putusan Mahkamah Agung RI Nomor 1644 K/Pid/1988 tanggal 15 Mei 1991 dimana dalam ratio decidendi putusan disebutkan bahwa apabila seseorang melanggar hukum adat kemudian Kepala dan Para Pemuka Adat memberikan reaksi adat (sanksi adat) maka yang bersangkutan tidak dapat diajukan lagi (untuk kedua kalinya) sebagai terdakwa dalam persidangan Badan Peradilan Negara (Pengadilan Negeri) dengan dakwaan yang sama melanggar hukum adat dan dijatuhkan pidana penjara menurut ketentuan KUH Pidana (Pasal 5 ayat (3) sub b UU drt Nomor 1 Tahun 1951) sehingga dalam keadaan demikian pelimpahan berkas perkara serta tuntutan Kejaksaan di Pengadilan Negeri harus dinyatakan tidak dapat diterima (niet ontvankelijk Verklaard).

Konklusi dasar dari yurisprudensi Mahkamah Agung tersebut menentukan bahwa Mahkamah Agung RI sebagai Badan Peradilan Tertinggi di Indonesia tetap menghormati putusan Kepala Adat (Pemuka Adat) yang memberikan sanksi adat terhadap para pelanggar norma hukum adat. Badan Peradilan Umum tidak dapat dibenarkan mengadili untuk kedua kalinya pelanggar hukum adat tersebut dengan cara memberikan pidana penjara (ex Pasal 5 ayat (3) sub b UU dart Nomor 1 tahun 1951 jo pasal-pasal KUH Pidana). Oleh karena itu, konsekuensi logisnya dapat dikatakan bahwa bila Kepala Adat tidak pernah memberikan sanksi adat terhadap pelanggar hukum adat, maka hakim badan peradilan negara berwenang penuh mengadilinya berdasarkan ketentuan Pasal 5 ayat (3) sub b UU dart Nomor 1 tahun 1951 jo pasal-pasal KUH Pidana.

Hukum adat sebagai hukum asli Indonesia merupakan hukum yang senantiasa mengikuti jiwa dari bangsa masyarakat Indonesia, karena senantiasa tumbuh dan hidup dari kebudayaan masyarakat tempat hukum adat itu berlaku dan hukum adat merupakan salah satu penjelmaan dari kepribadian, jiwa dan struktur masyarakat/bangsa. Hal ini sejalan dengan pendapat Von Savigny, yang menyatakan bahwa isi hukum ditentukan oleh perkembangan adat istiadat dan isi hukum ditentukan oleh mazhab sejarah atau sejarah masyarakat dimana hukum itu berlaku. ${ }^{34}$

Apabila di masyarakat ada sebagian yang berpendapat bahwa hukum adat sudah mengalami perlunakan berlakunya pada era modern seperti ini, memang pendapat tersebut ada benarnya. Fakta ini didukung oleh kenyataan bahwa sistem hukum yang dipakai di negara kita adalah sistem Eropa Kontinental. Pada sistem Eropa Kontinental, hukum tertulis (peraturan

${ }^{33}$ Lilik Mulyadi, Eksistensi Hukum..Op.Cit, hlm 237

${ }^{34}$ Von Savigny mengajarkan bahwa hukum mengikuti volksgeist (jiwa/semangat rakyat) dari masyarakat tempat hukum itu berlaku. Karena volksgeist masing-masing masyarakat berbeda, maka hukum masyarakat juga berbeda. Ajaran hukum ini lebih mengakui eksistensi dari hukum yang timbul dari masyarakat, jika dibandingkan dengan hukum tertulis. Alasan utama yang mendasarinya hal tersebut, karena hukum tertulis tidak selalu mencerminkan hukum yang hidup di masyarakat. Ajaran Von Savigny ini merupakan pencerminan berlakunya hukum adat di Indonesia. 
perundang-undangan) lebih mempunyai fungsi yang lebih besar di dalam penyelenggaraan negara maupun pengaturan masyarakat, jika dibandingkan dengan hukum yang tidak tertulis. Dengan sistem Eropa Kontinental tersebut, hukum yang lebih dominan adalah yang tertulis, dan hukum yang tidak tertulis (termasuk di dalamnya hukum pidana adat) disebut sebagai pelengkap saja. Akibatnya selama suatu masalah telah diatur di dalam perundang-undangan dan ternyata isinya bertentangan/berbeda dengan hukum adat, maka secara yuridis formal, yang berlaku adalah hukum tertulis. Namun yang perlu diingat bahwa dalam praktik di masyarakat terkadang hukum tertulis tidak selamanya sejalan dengan perkembangan di masyarakat, sehingga aturan yang tertulis tidak dapat menyelesaikan masalah-masalah yang ada dan terkadang tidak mencerminkan rasa keadilan di dalam masyarakat. Jika hal ini terjadi, maka berarti terjadi kesenjangan antara hukum tertulis dengan hukum yang hidup di masyarakat. ${ }^{35}$

Pada kasus demikian, maka hukum tidak tertulislah (hukum adat) nantinya yang akan menyelesaikan masalah tersebut. Hal ini nampak dari amanat UU No. 48 Tahun 2009 tentang Kekuasaan Kehakiman. di atas, yang memberikan keleluasaan kepada hakim untuk memahami, menggali dan mengikuti nilai-nilai hukum yang ada di masyarakat. Dengan demikian eksistensi hukum pidana adat di masa yang akan datang, harus tetap mempunyai peranan yang penting, terutama dalam pembentukan hukum nasional yang akan datang. Hukum pidana adat dapat menjadi salah satu sumber utama dalam pembentukan hukum tertulis, sehingga aturan tertulis tersebut otomatis merupakan pencerminan dari hukum masyarakat dan tentu saja dengan harapan ketika hukum tertulis tersebut sudah diberlakukan, dalam praktik di masyarakat tidak terjadi lagi kesenjangan dengan law in action-nya.

\section{G. Kesimpulan}

1. Aksiologi hukum pidana adat merupakan bahan hukum asli Indonesia yang sudah sepatutnya dijadikan sumber hukum positif. Namun, hingga saat ini hukum Indonesia masih menerapkan hukum Hindia Belanda, misalnya dalam lapangan hukum pidana, hukum kodifikasi Hindia Belanda masih diterapkan di Indonesia. Seperti halnya yang terjadi di Indonesia, hakim memutus perkara mengutamakan hukum tertulis sebagai sumber utamanya. Sehingga Aksiologi Produk hukum sendiri akan melahirkan formalistik semata di mana kepastian hukum menjadi ikon kebenaran. Keadilan adalah keadilan yang terdefinisi atas apa yang tertulis dan menutup diri atas keadilan yang selama ini tidak termaktub dalam suatu teks perundangundangan. Teori ini mengidentikkan hukum dengan undang-undang. Tidak ada hukum di luar undang-undang dan satu-satunya hukum adalah undangundang.

${ }^{35}$ Eka Susylawati, EKSISTENSI HUKUM ADAT DALAM SISTEM HUKUM DI INDONESIA, http://ejournal.stainpamekasan.ac.id/index.php/alihkam/article/download/ 267/ 258, diakses pada tanggal 25/02/2020 
2. Eksistensi hukum pidana adat di masa yang akan datang, harus tetap mempunyai peranan yang penting, terutama dalam pembentukan hukum nasional yang akan datang dan hukum pidana adat merupakan hukum yang hidup dan akan terus hidup, selama ada manusia dan budaya ia tidak akan dihapus dengan Perundang-undangan, andaikata diadakan Perundangundangan yang akan menghapuskannya akan percuma saja, justru hukum pidana Perundang-undangan akan kehilangan sumber kekayaannya oleh karena hukum pidana adat lebih dekat hubungannya dengan antropologi dan sosiologi dari pada hukum Perundang-undangan. Begitu pula dalam kajian hukum pidana maka eksistensi hukum pidana adat Indonesia berada pada tataran dogmatik hukum, teori hukum dan filsafat hukum. Oleh karena itu hukum pidana adat secara holistik menjiwai seluruh lapisan ilmu hukum yang pada hakikatnya hukum pidana adat tidak diragukan kapabilitasnya sebagai karakteristik praktek hukum di Indonesia. Dengan demikian eksistensi hukum pidana adat di masa yang akan datang, harus tetap mempunyai peranan yang penting, terutama dalam pembentukan hukum nasional yang akan datang.

\section{H. Saran}

1. Pola berpikir positivisme hukum dalam menegakan hukum hanya terbatas kepada menegakkan bunyi undang-undang saja dan tidak berkehendak menegakan keadilan dengan substansi hukum itu sendiri. Pola berpikir positivisme perlu diubah ke dalam doktrin keadilan dan kemanfaatan, sehingga keadilan substantive dan keadilan sosial dapat tercapai. Hakim harus kreatif dan tidak terbelenggu dengan rumusan norma dalam undangundang, dengan mendasarkan pada nilai-nilai yang hidup dan berkembang dalam masyarakat.

2. Pemerintah dan lembaga eksekutif perlu merevisi undang-undang dengan tetap memberikan pengakuan terhadap peradilan adat dan hukum-hukum adat. Tidak hanya menginternalisasi nilai-nilai adat ke dalam peradilan negara tetapi juga memberikan ruang pengakuan terhadap praktik peradilan adat di luar sistem peradilan pidana terutama pada wilayah-wilayah yang hukum adatnya masih kuat. 


\section{DAFTAR PUSTAKA}

\section{A. Buku :}

Achmad Ali., Menguak Teori Hukum (Legal Theory) dan Teori Peradilan (Judicialprudence), Kencana Prenada Group, Jakarta, 2009.

Barda Nawawi Arief, Beberapa Aspek Pengembangan Ilmu Hukum Pidana (Menyongsong Generasi Baru Hukum Pidana Indonesia), Pidana Pengukuhan Guru Besar, Fakultas Hukum Universitas Diponegoro, Semarang, 1994.

Hadikusuma, Pengantar Ilmu Hukum Adat Indonesia. Mandar Maju, Bandung, 2003.

Johnny Ibrahim, Teori dan Metodologi Penelitian Hukum Normatif, Bayumedia Publishing, Cet. IV, Malang, 2008.

Jonaedi Efendi, Johnny Ibrahim, Metode Penelitian Hukum Normatif dan Empiris, Prenadamedia Group, Depok, 2018.

Lili Rasjidi, Dasar-dasar Filsafat Hukum, cet. VII, Citra Aditya Bakti, 1996, Bandung.

Satjipto Rahardjo, llmu Hukum, P.T. Citra Aditya Bakti, Bandung, 1991.

Sugiyono, Metode Penelitian Kuantitatif, Kualitatif dan $R \& D$, Cetakan Kesembilan, Alfabeta,Bandung, 2010.

Surojo Wignjodipuro, Pengantar dan Azas-Azas Hukum Adat, Alumni, Bandung, 1979.

Theo Huijbers, Filsafat Hukum Dalam Lintasan Sejarah, Kanisius, Yogyakarta,1982. 
Uma Sekaran, Research Methods for Business, A Skill-Building Approach, Illionis: Southern Illionis University at Carbondale (SIUC), 1984.

W. Friedman., Teori dan Filsafat Hukum, Telaah Kritis atas Teori-teori Hukum (susunan I), diterjemahkan dari buku aslinya "Legal Theory" oleh Mohamad Arifin., Rajawali, Jakarta., 1990.

Legal Teori, alih bahsa Mohammad Arifin, Teori dan Filsafat Hukum : Idealisme Filosofis dan Problem Keadilan, cet. I (Jakarta, CV. Rajawali, 1990.

Zulkarnain, Kritik Terhadap Pemikiran Hukum Madzab Sejarah, Digitized by USU digital library, 2003

\section{B. Peraturan Perundang-undangan}

Undang-Undang Dasar Negara Republik Indonesia Tahun 1945.

Kitab Undang-undang Hukum Pidana

UU No. 1/Drt/1951 tentang Tindakan-Tindakan Sementara Untuk Menyelenggarakan Kesatuan Susunan Kekuasaan Dan Acara Pengadilan-Pengadilan Sipil

\section{Sumber Lain:}

\section{Jurnal dan Makalah}

Lilik Mulyadi, Eksistensi Hukum Pidana Adat Di Indonesia : Pengkajian Asas, Norma, Teori, Praktik dan Prosedurnya, Jurnal Hukum dan Peradilan, Volume 2 Nomor 2 Juli 2013.

Lintong O. Siahaan, "Peran Hakim Dalam Pembaharuan Hukum di Indonesia", Jurnal Hukum dan Pembangunan, Tahun ke 36 No.1 Januari 2006, Fakultas Hukum Universitas Indonesia, Jakarta. 2006

Mahkamah Agung, Varia Peradilan, Tahun ke VI, No. 72, September 1991

Mahkamah Agung, Varia Peradilan, Tahun ke XII, No. 151, April 1998

Nyoman Serikat Putra Jaya, Hukum (Sanksi) Pidana Adat Dalam Pembaharuan Hukum Pidana Nasional, Masalah - Masalah Hukum, Jilid 45 No. 2, April 2016.

Rusli Muhammad, "Kajian Kritis Terhadap Teori Hukum Positif (Positivisme)", Jurnal Hukum Respublica, Vol. 5, No. 2, Tahun 2006, Fakultas Hukum Universitas Lancang Kuning (Unilak), Pekanbaru 2006 


\section{Internet}

Eka Susylawati, EKSISTENSI HUKUM ADAT DALAM SISTEM HUKUM DI INDONESIA, http://ejournal. stainpamekasan.ac.id/ index. php/ alihkam/article/download/267/ 258,diakses pada tanggal $25 / 02 / 2020$

Galuh Faradhilah Yuni Astuti, Relevansi Hukum Pidana Adat Dalam Pembaharuan Hukum Pidana di Indonesia https:// journal. unnes.ac. $\mathrm{id} / \mathrm{nju}$ /index.php/ pandecta/ article/ download/ 4953/ 4102, diakses pada tanggal $25 / 02 / 2020$

Mahrus Ali, Fondasi Ilmu Hukum Berketuhanan: Analisis Filosofis terhadap Ontologi, Epistemologi, dan Aksiologi, https://journal. unnes.ac.id/nju/index.php/ pandecta/ article/ view/7844. Dikases pada tanggal $25 / 02 / 2020$

Odie Faiz Guslan, dominasi positivisme hukum dan eksistensi hukum adat dalam sistem hukum nasional https:// rechtsvinding. bphn.go.id/ jurnalonline/edit $\% 20$ Naskah\%

JRV\%20Online\%20DOMINASI\%

POSITIVISME\%20HUKUM\%20DAN\%20EKSISTENSI\% 20 HUKUM\%20ADAT\%20DALAM\%20SISTEM\%20HUKUM\%20N ASIONAL.pdf. . Dikases pada tanggal 25/02/2020 